Klemen PLOŠTAJNER, Hajdeja IGLIČ*

\title{
DENSIFICATION, RENT AND USE VALUE: SPATIAL CONFLICTS IN ROŽNA DOLINA, LJUBLJANA
}

\begin{abstract}
Since 2015, the residential neighbourhood of Rožna dolina has experienced intense building activity that has been supported by the city of Ljubljana, but has been met with resistance from the local inhabitants, thus becoming the most visible local expression of the universal capitalist conflict between the use and exchange value of space. The article main aim is to analyse the concrete manifestation of this conflict by looking at the operations of the local state, investors and inhabitants in the production of space in Rožna dolina. The analysis shows that the conflict is influenced by the specific local state's dependency on economic actors, by specifics of local real estate market and workings of developers and by the composition of inhabitants of Rožna dolina. Keywords: Ljubljana, spatial conflicts, appropriation of rent, local state, real estate development
\end{abstract}

\section{Introduction}

In 2015, the first high-end multi-apartment project following the economic crash of 2009 was completed at the northern end of Rožna dolina, a residential neighbourhood near to the city centre of Ljubljana (the capital of Slovenia). The building consists of five units and multiple underground parking garages, which were promptly sold to wealthy individuals. The investor, a successful entrepreneur from a well-to-do Slovenian family, bought the empty plot in 2006 during the last real estate boom (2004-2008), but needed to wait for the next one (from 2015 onwards) to realise the project. After the initial success of this particular investment and despite the local inhabitants' resistance, new projects followed and Rožna dolina soon became one of the most interesting neighbourhoods for real-estate investors. The article focuses on the structural changes that have led to the intense construction activity seen in the area and analyses the spatial conflicts it has produced.

* Klemen Ploštajner, MSc, Junior Researcher, Faculty of Social Sciences, University of Ljubljana, Slovenia; Hajdeja Iglič, PhD, Associate Professor, Faculty of Social Sciences, University of Ljubljana, Slovenia.

DOI: $10.51936 /$ tip.58.3.901-917 
In order to explain these changes, we utilise the power-conflict approach to the production of space in connection with the core ideas of the "growth coalition theory" (Logan and Molotch, 1987/2007), urban land rent analysis, and analysis of the local state. We especially focus on the concrete local manifestation of the conflict between the use and exchange value of space, namely, a universal characteristic of capitalist spatial relations. This conflict is being mediated through the actual social, political and economic relations among three types of actors: the municipality (local state), real-estate investors, and the local inhabitants. Our main research question aims to answer how is this universal conflict specially structured in the relationships of three actors in Rožna dolina's spatial development. More specifically, how are specific structural positions of three actors in Ljubljana influencing the nature of spatial conflicts, their emergence, development and potential, but always partial resolution. To answer this question, we utilize case study method and analyse the operation of three actors in Rožna dolina since 2015 by using wide variety of sources like newspaper articles, construction permits, city's developmental strategies and public statements, company reports and public statements from local movements.

The article consists of two parts. In the first part, we develop the theoretical arguments against the dominant idea of cities' unitary city interest and a benevolent local state that works in the locality's general interest. Our argument stresses the need to focus on the role which the conflict between the exchange and use value of space plays in developing the city's space. We further develop the classical "growth coalition theory" by adding to the analysis the role played by the local state in producing, mediating and partially resolving spatial conflicts. Given that we utilise a theoretical framework that was developed in the United States, we are careful to not uncritically transmit its core arguments to a different social context (Harding, 1991). In the second part, we use this theoretical framework to analyse the changes in Rožna dolina by contextualising the conflict between the exchange and use value of space in a particular local setting of Ljubljana.

\section{Theory: from "unitary interest" to a power-conflict approach}

A common theme in contemporary analyses of urban development is the idea of cities in a global competition for mobile flows of different forms of capital (Peck et al, 2009; MacLaren and Kelly, 2014; Minton, 2017; Stein, 2019). The main goal of urban politics thus revolves around developing an appropriate environment for attracting outside resources regarded as necessary for local development. Cities and especially municipal governments are perceived as entrepreneurial actors that need to mobilise and develop their competitive advantages against other cities. One of the main 
ones is the quality of the urban environment, which is no longer: "an outcome of economic growth ... [but] has become a prerequisite for the economic development of cities" (Gospodini, 2002: 60). Foreign investments or consumption flows are essential not only for cities to grow, but are also regarded as the main engine that heightens the general quality of life. Cities which do not attract foreign flows and are not competitive face the threat of disinvestment and gradual deterioration. For these reasons, it is widely accepted by most city administrations that it is in the general interest of the city as a whole to pursue developmental policies to compete against other localities in the national and international arenas.

These ideas are not new nor without historical precedent, for similar ones were advocated in theoretical discussions in America in the 1970s and 1980s when cities encountered a severe fiscal and social crisis. They were most eloquently captured in the "unitary interest thesis" developed by Paul Peterson in City Limits (1981). The book claims that city politics is limited by its inability to control flows of people and capital. Outside limitations mean that cities' interests are not determined so much by their internal struggles, but are instead shaped by their general dependence on local economic growth. Peterson deduces two general conclusions from this. First, because cities depend on being able to entice mobile capital and labour, the flows of which they are unable to control, their policy choices are limited to developmental policies that try to catch them ${ }^{1}$. Other forms of policies, especially redistribution, harm cities' economic position and are thus destructive in the long run. Second, these limited options also mean that developmental policies are in the general interest of the whole population because they are a precondition for the market-based, trickle-down redistribution. The city and its population are assumed to have a unitary interest in economic development that rules over almost all of the preconditions for genuine political conflict.

Peterson's thesis has exerted a big influence on public policy arguments, although his conclusions were critically commented on by various theoretical camps (e.g. Harvey, 1989; Stone, 1993). One of the biggest criticisms came from Molotch and Logan, who developed the "growth coalition theory" and based it on the idea that developmental policies are the product of local political domination by parochial landed interests which pursue economic rent (Molotch, 1976; Logan and Molotch, 1987/2007). Their interests are localised and tied to the ownership of immobile land or real estate. This spatial fixity means their pursuit of economic rent, which is derived from the intensification of land use, is connected to the general growth of

1 While Peterson was advocating the enticement of the export industry, authors are today more focused on culture, human capital and the quality of the urban environment (see especially Florid, 2002). 
the city. Because cities compete with other localities and their landed interest, they try to influence municipalities' decisions to attract mobile capital, thereby intensifying land use. Cities' pursuit of economic success through developmental policies is hence in the interest of local property elites, for whom: "...the city is a growth machine, one that can increase aggregate rents and trap related wealth for those in the right position to benefit" (ibid.: 50). Molotch and Logan thus show that developmental policies which stress economic growth are not in the general interest of the whole population and may even be harmful for some.

Cities' policies are therefore not a product of unitary interest, but are produced by internal conflicts which also structure the space in cities. Of these, the central one is the conflict between the exchange and use value of space that is derived from its commodity status and thus its dual character in capitalism (Vance, 1971). On one hand, space is treated as a fictitious capital (Harvey, 2006) whose exchange value is determined by the future stream of income produced by activities on the land. Place entrepreneurs try to intensify activities on the land to heighten its yield. However, space is also characterised by its use value, which is denoted by daily routine, informal support networks, safety and trust, local identity, agglomeration, access 904 and other qualities. These use values are threatened by the exchange value, especially by the intensification of and changes in land use. The commodity status of land and exchange value interest of place entrepreneurs are a threat to the stability and well-being of the neighbourhood (use value), which: "is the meeting place of the two forces, where each resident faces the challenge of making a life on a real estate commodity" (Logan and Molotch, 1987/2007: 99).

This conflict between use and exchange value is not played out in a vacuum, but is mediated, regulated and in a way also enabled by the organisation of the local and national state. As McAdams claimed, "land use involves a struggle between conflicting actor groups, and this struggle surfaces largely in governmental decision-making processes" (1981: 300). It is thus necessary to analyse the role of the local state in mediating spatial conflicts. Growth coalition theory lacks the theory of the state and sees the political realm as an arena that is instrumentally used by the local landed elite to promote and protect exchange values extracted from land. This perspective erases the relative autonomous political sphere and cannot explain the fact that elites are not always the automatic winners of spatial conflicts (Whitt, 1982). While we need to maintain the analysis of the role of elites in the production of space, we must situate it in a broader structural analysis of the state that better explains the dominant, albeit limited, power of the elites.

On the structural level, one of capitalist societies' main characteristics is the separation of politics and economics (Meiksins Wood, 1981; Stone, 
1993). In the production of space, these are manifested as the separation between the private control of land and investment capital and the public control of regulation and infrastructure. Cities thus do not have their own resources to develop space, but are structurally dependent on private actors in the pursuit of local development (Stone, 1993). Still, because land is fixed, its value is socially produced, and its realisation timely and complex (RyanCollins et al., 2017), place entrepreneurs also depend on different state functions to extract exchange value. While historically planning was conceived as a tool for rationalising the urban environment and addressing the negative externalities of private development, it is nowadays ever more moving in the direction of promoting land values.

"This is the real estate state, a government by developer, for developers" (Stein, 2019: 21). The regulation of land is hence increasingly occupied by two goals: the production of space's exchange value, and the legitimation of these processes. One mechanism of the production of the exchange value of space is the local production of rent gaps through changes in the regulation of space. The idea of a rent gap (Smith, 1979) stipulates that the growing gap between capitalised ground rent (current use and exchange value) and potential ground rent (higher exchange value due to changes in the space) enables a profitable redevelopment of space. While classical analyses have focused on devaluation of the current use through the process of blight (the fall of capitalised rent), today's processes are more marked by the growth of potential ground rent (Hackworth, 2007) through intensified land use. The local state can widen the rent gap through spatial regulation by allowing changes in land use and the private appropriation of regulatory produced planning gains. Under neoliberalism, this role is gaining in importance due to the growing emphasis on urban and spatial development. Ossen highlights this role of the local state in Sweden's reform of municipal land instruments:

One central and important function of the municipal land instrument under neoliberalization, I argue, is to remove this landowner-developer antagonism, so as to enable developers to appropriate a large part, if not all, of the land rent. This leads to the seemingly contradictory tendency by municipalities to act as rent-maximizing landowners, at the same time as they refrain from capturing, or capture only a minimal part of, the future land rent. (2019: 645)

Under the neoliberal paradigm, the local state is thus increasingly mediating spatial conflicts in line with the needs of place entrepreneurs who are pursuing exchange value at the expense of use value for the local inhabitants. Still, the conflict and the state's role in it is not directly visible for it is 
covered by the idea of the unitary interest of the city and its whole population in economic growth and the intensification of land use. The political nature of conflict is also hidden by reducing spatial questions to the level of technical expertise that determine whether a real-estate development is in accordance with the specific technical requirements. Both of these mechanisms - unitary interests and the technical nature of the debate - depoliticise spatial conflicts and narrow the set of actors which participate in it. They also portray the city's spatial development as a neutral question of realising the city's developmental goals and not as a product of the conflict between use and exchange value.

\section{Spatial conflicts in Rožna dolina, Ljubljana}

We use the above theoretical framework to analyse spatial conflicts in Rožna dolina by focusing on the operation and relationships between three main actors: the Municipality of Ljubljana, real-estate investors, and the local inhabitants. The empirical analysis is based on media reports (Pahor, 2016; 2017a; 2017b; 2019a; 2020; Brkić, 2018; Petkovšek, 2017a; 2018; Zabukovec, 2018), public documents (Mestna občina Ljubljana, 2011; Mestna občina

906 Ljubljana, 2010a) and other publicly accessible information about investors and their projects.

Rožna dolina is a small neighbourhood of around 7,000 people located near to the city centre and the city's biggest green area Rožnik, dominated by villas with big private gardens and perceived to be one of the most affluent parts of Ljubljana. In earlier housing booms, the area did not experience too much construction activity due to the particular building structure of its lots (too small for bigger projects and too big for individual housing units) and the restrictive spatial regulation. This changed in 2010 when the city adopted a new spatial plan for the area that allows higher and denser development. While the area became interesting for place entrepreneurs, their ability to develop was limited by the financial crisis and credit crunch which lasted until 2014. After 2015, numerous projects followed that were accompanied by the protests of local inhabitants who felt their use value of the space was being threatened by the denser construction. By informally organising (forming the Civil initiative Rožna dolina), lobbying the city administration and taking a couple of construction permits to court, the local inhabitants forced the city to amend its spatial plan in 2018 and were able to delay the realisation of two larger projects. Yet, because the city plan still allows denser construction in certain parts of Rožna dolina - especially on three bigger land plots owned by important developers, the area is still experiencing intense construction activity. 


\section{The Municipality of Ljubljana: Informality and densification}

While we may claim that the city administration is functioning as a growth machine that promotes and stimulates real-estate investment, we cannot uncritically apply the American models to analyse this. The main reason for this is the different structure of the local state and its relation to the national one, meaning that its instruments, financial resources and obligations are not the same as the American ones (Kukovič et al., 2016). Slovenia's municipalities are much less autonomous and have far fewer instruments available for local development disposal. They are unable to determine the level of taxation (except for some minor expenses) or offer tax relief, cannot subsidise private development or offer special deals in relation to it. At the same time, municipalities depend far less on local taxes for their primary functions, which are chiefly financed from the national budget. However, while local social services are financed by the central state, the national budget does not offer enough funds for local spatial development. Not only that, the central state is also substantially failing to realise its own spatial projects and underfunding spatial development, especially housing construction. Municipalities are thus unable to rely on national state resources for their developmental goals, and depend on local resources (mostly different real-estate-related taxes and sales of municipal land), private developers or EU funds to realise them. We may claim that Slovenia's municipalities do not depend on local resources for social provision, but do depend on local resources, private investors and entrepreneurial activity (applying for EU funds) to realise their developmental goals. Ljubljana, the biggest and most economically advanced area, has been in the best position to utilise these different tools to pursue its developmental goals by promoting private investment. Still, due to the lack of formal instruments to promote private development, the city has been forced to rely on more indirect and informal tools.

On the most general level, Ljubljana is promoting private investment by following its own urban redevelopment plan enshrined in the developmental document Vision 2025 (Ljubljana, 2007). In its campaign of regeneration, the city started to heavily invest in different real-estate projects, the main ones being redevelopment of the city centre and construction of the Stožice sporting arena, while at the same time developing new identity different promotional campaigns for the city, collecting different awards and international titles (Green Capital of Europe, UNESCO City of Literature etc.). Through public statements, promotional campaigns (visiting the MIPIM international real-estate fair), public-private partnerships and different informal agreements the city also actively promoted and supported private real-estate investments. Even more, the city administration has publicly 
recognised that it does not have the resources to realise its developmental goals and that it partly counts on private investments to make them a reality (ibid.).

These has been most visible with the housing question, an area underfunded by the state budget. The main tool for promoting housing development has been densification of the city space through regulation of the urban environment in a spatial plan adopted in 2010 (Mestna občina Ljubljana, 2018). With it, Ljubljana started to encourage new construction on empty or underutilised plots in already urbanised areas by allowing investors to build higher and denser projects with fewer open or green areas. Densification has lain at the heart of the city's housing policy, that is largely extent based on the idea that private construction will lead to lower housing prices $^{2}$. However, the densification of the city's space is not only connected to housing, but is also part of the city's sustainable and cultural regeneration (Ljubljana, 2007; Kos, 2008). Filling empty or underutilised plots with higher and denser construction would enable the pursuit of greener ways of life (e.g. walking instead of driving) and the development of urbanism as a way of life. Densification is perceived as a tool of regeneration by attracting younger and more affluent inhabitants ${ }^{3}$, while at the same time acting as the main tool for sustainable urban transformation ${ }^{4}$.

Still, densification has also led to the growth of potential rent, as extracted through higher prices of land or denser construction. Without mechanisms to publicly extract the rent created by densification, the majority is appropriated by private investors. Even more, the city promotes densification, while not prescribing any social or environmental regulations for denser construction. Ljubljana thus acts in a similar role as the Swedish municipalities described by Olsson: producing rent without extracting it. Without strict regulations and linking the appropriation of rent to social or environmental goals (e.g. constructing a certain amount of social housing), place entrepreneurs develop the most profitable projects. "Higher density has always been a scheme for growing rents; developers consistently lobbied for more on less. They didn't give a hoot about environment or social diversity" (Logan and Molotch, 1987/2007: xx). For these reasons, the densification in Rožna

2 In public addresses, the mayor has repeatedly claimed that the city's new spatial plan enables the construction of 40,000 new apartments (Mekina, 2018).

3 These gentrification tendencies are expressed explicitly: "With inbuilding of flats into multifunctional buildings, the city centre will preserve urbanity, while at the same time increase the share of inhabitants of higher social standing" (Ljubljana, 2007: 12).

4 As the deputy mayor claimed: "First, I must say, that building in height is sustainable construction and is typical for inbuilding in city centre or those parts of the city, that are already urbanized and are part of strategy of urban renewal. This means, that punctiform inbuilding is the easiest insertion of generators of development on empty or cleared plots and will have an invigorating effect on its surrounding" (Kos, 2008). 
dolina has not addressed housing or environmental question, but entailed high-end projects with expensive apartments and underground parking places.

While most investors simply aim to extract potential rent by building as dense as possible, bigger investors also use their special status to achieve a better market position. Rožna dolina contains three bigger plots of land that are owned by stronger market players and allow for even higher densities. It is interesting that in the past all of these land plots were considered as spaces for public infrastructure (parks, playgrounds, student dormitories, school, communal spaces) and one was even owned by the municipality up until 2016 (Brkić, 2016). In all three cases, the municipality allowed investors to build higher and denser projects by passing a special spatial regulation for these plots (Mestna občina Ljubljana, 2010b; Mestna občina Ljubljana, 2011). In all cases, private investors took advantage of their position of power for: "political rent-seeking' ... created by lobbying, bribery, favourable tax treatments and subsidies" (Haila, 2016: 70). However, we cannot attribute these relations simply to the elite instrumental domination of the local state, nor to the corruption of city officials, but instead must consider the local state's limited capacity and the question of reciprocity between private investors and the municipality. All three investors which have received preferential treatment in Rožna dolina have in the past cooperated with the city and helped it realise certain public goals. As mentioned, the municipalities in Slovenia depend on private investment to realise their developmental goals. They need to cooperate with private investors, but lack formal instruments ${ }^{5}$ to link private investment to public goals. This lack of linkage policies, which would impose fees (financial or social) in exchange for more generous developmental rights, means that Ljubljana must resort to informal practices to stimulate growth ${ }^{6}$. Namely, developmental deals and growth coalitions in Ljubliana operate in informal ways ${ }^{7}$, thereby concealing reciprocity from public control.

5 Through these mechanisms, private investors receive preferential treatment from the local state (like grants, tax reliefs or special zoning approvals), but must provide certain public benefits in exchange for them (like bus stops, parks, public spaces, affordable cities...).

6 This logic was even publicly declared by the Mayor Zoran Jankovic who in 2010 claimed that all companies that make profit in Ljubljana should return something to the local environment by donating to certain causes. These arrangements are informal and leave a lot of room for coercion, which lead to the accusations of malpractice and extortion. In one case, the mayor was taken to court, but was acquitted of all charges (Brkić, 2010; Krivec, 2019).

7 Ljubljana promotes itself as a friendly investment environment with an entrepreneurial city admin istration. In a magazine from 2017 that promotes Slovenia to foreign investors, the informality of the developmental policy was evident in the statement: "Mayor Zoran Janković plays a key role in all important projects in the City of Ljubljana" (Slovenia Times, 2017: 41). 


\section{Investors: Structure of Rent Maximisation}

Molotch and Logan (1987/2007: 29-31) distinguish three different types of place entrepreneurs: the serendipitous (for whom exchange value is more a random opportunity than a central activity), the active (active speculation that follows general trends) and the structural (actively producing trends and changing the land market structures through political activity) We can identify all three of them in Rožna dolina. Structural place entrepreneurs are the three bigger investors which are maximising rent through the political process, informal arrangements with the city administration and preferential treatment in spatial regulation. Active entrepreneurs are all the other investors who are maximising their rent extraction by following the trends and actively seeking out investment opportunities. Such opportunities have been offered by the densification process, low interest rates and higher purchasing power of the more affluent. The final ones are serendipitous entrepreneurs, who do not actively seek rents (their income is not based on speculative real-estate investment), but happen to own interesting land plots. In this group, we may find all inhabitants of Rožna dolina who are prepared to substitute the use for the exchange value of space due to the

910 spike in housing prices 8 . They are mostly selling to the active entrepreneurs, who then either develop the project or resell the land.

How can we explain the sudden interest of investors in Rožna dolina since 2015? Besides the changes in spatial regulation that allowed for the area's densification, three other factors should be considered. First, the changes in the structure of real-estate investors in Slovenia, which was once dominated by big construction companies mostly interested in bigger housing projects with more than 100 units and marketed to the population with average. They dominated the market during the construction boom of 2004 and 2008 and were enabled by the lax banking lending activity. When in 2009 housing prices started to fall and banks experienced liquidity problems, most of the bigger companies declared bankruptcy and the construction industry collapsed. With most of the bigger companies gone, the vacuum in the housing market was filled by a proliferation of small real-estate investment companies. These changes also led to changes in investment activity, moving from big housing developments to more modest, high-end projects, which smaller companies can develop and banks are prepared to finance. The space for investment opportunities has thus been altered by the changes in the industrial structure of real-estate investors. While bigger

8 The Civil initiative Rožna dolina is aware of these serendipitous temptations. In the invitation to its meeting on 30.1.2020, it was written: "Investors are 'waiting' for your neighbour to sell their real estate, so you can never know, when your closest living place will be threatened" (Flyer 1). 
companies were seeking big cheap plots of land, nowadays smaller companies are looking for smaller plots with the potential for elite development. Rožna dolina is thus suitable for smaller investors and has not been as interesting for bigger ones.

The second factor is connected to investors' limitations and capabilities. Particular real-estate projects are not just the realisation of investors' interest or perceptions of market opportunities, but are structured by "the interaction between economic, communal, and ideological forces at a particular historical moment" (Fainstein, 2001: 15). Chief structural forces that influence development are state regulation and industry structure (Coiacetto, 2009), access to finance and the structure of demand. The demand in Slovenia is dominated by homeownership, which limits real-estate housing investors to a certain kind of project that are in line with purchasing power and consumer preferences. Yet, capitalist companies are not in the business of just satisfying demand, but to do it for a profit. For this reason, every real-estate investor must find a way, in accordance with their capabilities, to profitably satisfy a particular demand that is backed by purchasing power. While during the first housing boom big companies were profiting from cheaper construction by standardising mass production, today's smaller investors are unable to increase profit by lowering expenses, but must resort to raising prices. Smaller, high-end projects are also more suitable for lending institutions, which in the past were overexposed to big construction companies and are now more careful in considering real-estate projects. Given that "supply is tailored to the risk and return requirements of capital..." (Weber, 2015: 81), these small projects are able to assemble the capital needed because they are seen as less risky (smaller loans mean less exposure). For smaller real-estate investors, small high-end projects thus seem to be almost their only profitable investment opportunity. These projects offer larger floorplans, are marketed as exclusive and need to be situated at better locations. Rožna dolina offers all of this.

Lastly, we need to consider the particular investment opportunities Rožna dolina is perceived to offer. In the past, Rožna dolina was protected from investors by its particular structure of plots, which are relatively expensive, by its status as an affluent neighbourhood and the symbolic value held by its morphology, and by its inhabitants' general affluence. The area's low density was a condition for the rent extraction because bigger individual plots and houses attracted higher prices. The low density and particular character it offered acted as an asset for inhabitants (protection against lower classes), but also for investors who were able to extract differential rent from the particular symbolic and spatial value of the existing housing structure. However, under certain conditions "exchange value pressures are sometimes so great that no community can withstand them, no matter how 
much wealth it has" (Molotch and Logan, 1987/2007: 122). In these conditions, the low density and affluence, which used to protect the neighbourhood against investors, suddenly become a development opportunity. "The political tensions in such areas represent the increasing disparity between the rent payoff of parcels under current low densities and the rent potential of the same parcels if they are turned over to more intensive uses" (ibid.: 122). Due to changes in the real-estate investors, their investment opportunities and capabilities, but also changes in the general politico-economic structure of Ljubljana, the densification of Rožna dolina has begun to be regarded a legitimate developmental strategy. Houses in Rožna dolina are hence no longer seen by investors as special housing units for renting or selling, but as pieces of bricks on land that can be redeveloped.

\section{Inhabitants: Who is able to protect the use value?}

Investors and their activity are also confronted by local inhabitants and their organisational capacity. For this reason, Molotch and Logan add two more conditions to the neighbourhood's fate: "(3) the power and status of residents in the larger political economy; and (4) the sentiments and cultural

912 systems of residents that guide the pursuit of local use value" (ibid.: 123). Inhabitants protect use value against investors who want to change the form or use of particular locations. In a classical gentrification manner, they wish to protect the current population and services from more profitable ones. This is also apparent in Rožna dolina where the inhabitants have organised to "prevent the degradation" (Zabukovec, 2018) of the area with "concrete boxes, plots without greenery, gardens or trees, flooded basements during the rain..." (ibid.). From their public statements, we may deduce two use values that they are protecting. The first is the safety and quality of their homes, which are threatened by possible flooding due to the new constructions' underground garages raising the level of underground water. This threat is also used in legal battles against the city's spatial plan or to resist certain construction permits. The second use value the inhabitants are protecting is more symbolic and connected to the area's general identity. They talk about the changes to the neighbourhood's special character through the destruction of older buildings and cultural heritage. This is generally connected to the use value of the area (sentiments, connection to the place, local identity...), but sometimes also to the exchange value (denser construction on the neighbouring plots is lowering the exchange value of their homes). The lines between protection of the use and the exchange value are usually blurred, especially when it comes to richer neighbourhoods. However, despite occasional hints at exchange value considerations, use value questions lie at the heart of the inhabitants' struggle in Rožna dolina. 
The ability to protect use value cannot be generalised to the whole city, but is conditioned by a particular neighbourhood's social composition. It is preconditioned by the ability to organise effective resistance, which may depend on the general standing of the neighbourhood and the different capitals the local inhabitants possess. While poor people "are not in a position to effectively claim that their neighbourhood, as used by them, is either a national resource or useful for attracting capital" (Molotch and Logan, 1987/2007: 135), the rich are and usually defend their neighbourhood as a general and not a particular use value. The other factor is the inhabitants' ability to organise and the need for different resources to accomplish this effectively. The rich have cultural and social resources to understand the hidden, technical and complex processes of spatial regulation, construction permits and banking activity. They have the means and contacts to intervene in these processes. This is evident in Rožna dolina where inhabitants with a better social standing have had the resources they needed to organise against place entrepreneurs. The particular social standing of the population has also led to a specific form of struggle, one dominated by legal tools (Pahor, 2019). The inhabitants have enough resources to fight legal battles against the city and certain investors. Their social status means they also see legal battles as the most effective and legitimate form of resistance. This kind of struggle also leads to the general depolitisation of the conflict because it becomes reduced to the technical questions of construction permits. In the case of Rožna dolina, the conflict has been reduced to the technical question of the level of ground water now being studied by two different expert groups (Pahor, 2020). The neighbourhood's future and realisation of two bigger projects now hang on expert opinions on the level of ground water and not the general well-being of the neighbourhood. Instead of a political discussion about the privatisation of land, the lack of public infrastructure, the unaffordability of build projects or the investors-city administration relationship, the hydrogeological profile of land is at the heart of the conflict.

While at first glance it appears to be a technical question, the spatial conflict in Rožna dolina is profoundly political in nature. However, its political nature was hidden until the inhabitants started to protest against realestate projects and the city's spatial plan. Consistent with the idea of unitary interest, the city has claimed the projects are technically and legally sound and that the local inhabitants are uneducatedly threatening urban sustainable development through the densification of land use 9 . The Municipality

9 The deputy mayor in an interview: "The biggest problem of the sustainable transformation of the city is the densification of the current built environment with inbuildings or alternative new houses, that always trigger the resistance of the neighbours and disturb surrounding inhabitants. This is a usual and expected reaction to the changes" (Pahor and Lesničar-Pučko, 2018). 
has perceived the investors' operation as a technical question of following the legal rules, while labelling the local protests as unnecessary politisation and an obstacle to development. As pointed out above, the citizens are also caught in a process of depolitisation by trying to build their own technical legitimacy. The inherent spatial conflict between use and exchange value is thus dually displaced. First, by the city, that views conflict as something foreign to the spatial development and, second, by the inhabitants of Rožna dolina, who are tactically focusing on the technical questions of flood protection to try to protect their neighbourhood. In both cases, the production of space is seen as a technical question, that is and should be decided by experts from different disciplines. All groups (investors, the city, the inhabitants) call different experts to their defence, thereby slowly pushing the conflict away from its most general level of: "who is the city for?".

\section{Conclusion}

Since 2015 the spatial development of Rožna dolina has become one of the most visible manifestations of the conflict between the use and exchange value of space in Ljubljana. It shows that there is no such thing

914 as a unitary interest of the city, but that particular spatial development is connected to different interests and conflicts. The conflict between use and exchange value is always present in capitalist societies, but its visibility and level of intensity are determined by the organisational capacity of the local inhabitants and the investment opportunities of place entrepreneurs. It is also mediated through and expressed in the workings of the local state, which is not a neutral mediator, but is characterised by its specific capitalist character and local political struggles. Our analysis focused on the question of the concrete manifestation of these universal relations in Rožna dolina by analysing structural positions and relations between place entrepreneurs, local state and local inhabitants in Ljubljana.

The analysis shows that the conflict is influenced by the relatively high local state's dependency on economic actors, by specifics of local real estate market and composition of developers and by the social composition of inhabitants of Rožna dolina. The local state that lacks public resources for spatial development has firmly accepted the idea of the city as a growth machine that needs to support and entice private investment activity thereby becoming highly dependent on economic actors. The specific industrial structure and opportunity space of real-estate investors including the smaller size and limited access to financial resources has been pushing them towards developing luxury projects allowing the highest profit levels by exploiting the rent gaps produced by the spatial plan. Finally, the relationship between investors and the city, as crystalised in the densification of urban space, is 
resisted by the local inhabitants whose relatively high socio-economic status enables them to launch somewhat effective, but limited resistance against construction activity in Rožna dolina. Their ability is connected to the local state's need to, in addition to supporting place entrepreneurs, also try to mediate social conflict in order to maintain its legitimacy by offering local inhabitants some concessions. Our analysis thus shows that place entrepreneurs, as main producers of space, and local state, as enabler of their investment strategies, are the main actors in the spatial development of Rožna dolina, while the role of local inhabitants is secondary, for they, despite being relatively effective, are mostly reacting to the decision made by others.

\section{BIBLIOGRAPHY}

Coiacetto, Eddo (2009): Industry Structure in Real Estate Development: Is City Building Competitive? Urban Policy and Research 27 (2): 117-135.

Fainstein, Susan (2001): The City Builders: Property Development in New York and London, 1980-2000. Lawrence: University of Kansas Press.

Florida, Richard (2002): The rise of the creative class: and how it's transforming work, leisure, community and everyday life. New York: Basic Books.

Gospodini, Aspa (2002): European Cities in Competition and the New "Uses" of Urban Design. Journal of Urban Design 7 (1): 59-73.

Hackworth, Jason (2007): The Neoliberal City: Governance, Ideology, and Development in Amrican Urbanism. Ithaca: Cornell University Press.

Haila, Anne (2016): Urban Land Rent: Singapore as a Property state. Malden: John Wiley \& Sons.

Harding, Alan (1999): North American Political Economy, Urban Theory and Britich Research. British Journal of Political Science 29 (4): 673-698.

Harvey, David (1989): From Managerialism to Entrepreneurialism: The Transformation in Urban Governance in Late Capitalism. Geografiska Annaler: Series B, Human Geography 71 (1): 3-17.

Kukovič, Simona, Miro Haček and Alan Bukovnik (2016): The Issue of Local Autonomy in the Slovenian Local Government System. Lex Localis - Journal of Local Self-Government 14 (3): 303-320.

Logan, John and Harvey Molotch (2007): Urban Fortunes: The Political Economy of Place. Berkley: University of California Press.

MacLaran, Andrew and Sinéad Kelly (2014): Neoliberal Urban Policy and the Transformation of the City: Reshaping of Dublin. Basingstoke: Palgrave Macmillan.

McAdams, Claire (1980): A Power-Conflict Approach to Urban Land Use: Toward a New Human Ecology. Urban Anthropology 9 (3): 295-318.

Meiksins Wood, Ellen (1981): The Separation of Economic and Political in Capitalism. New Left Review 127: 66-95.

Minton, Anne (2017): Big Capital: Who is London For? Milton Keynes: Penguin Books. 
Molotch, Harvey (1976): The City as a Growth Machine: Toward a Political Economy of Place. American Journal of Sociology 82 (2): 309-332.

Ossen, Lina (2018): The Neoliberalization of Municipal Land Policy in Sweden. International Journal of Urban and Regional Research 42 (4): 633-650.

Peck, Jamie, Nick Theodor and Neil Brenner (2009): Neoliberal Urbanisation: Models, Movements, Mutation. SAIS Review XXIX (1): 49-66.

Peterson, Paul (1981): City Limits. Chicago: The University of Chicago Press.

Ryan-Collins, Josh, Toby Lloyd and Laurie Macfarlane (2017): Rethinking the Economics of Land and Housing. London. Zed books.

Smith, Neil (1979): Toward a Theory of Gentrification: A Back to the City Movement by Capital, not People. Journal of the American Planning Association 45 (4): 538-548.

Stein, Samuel (2019): Capital City: Gentrification and the Real Estate State. London: Verso.

Stone, Clarence (1993): Urban Regimes and the Capacity to Govern: A Political Economy Approach. Journal of Urban Affairs 15 (1): 1-28.

Vance, James E. (1971): Land Assignment in the Precapitalist, Capitalist, and Postcapitalist City. Economic Geography 47 (2): 101-120.

Weber, Rachel (2015): From Boom to Bubble: How Finance Built the New Chicago. Chicago: The University of Chicago Press.

Whitt, Allen (1982): Urban Elites and Mass Transportation: The Dialectics of Power. Princeton: Princeton University Press.

\section{SOURCES}

Brkič, Vanja (2010): Župan Zoran Janković priznava, da je podjetjem predlagal donacije. Dnevnik. Accessible at https://www.dnevnik.si/1042349616, 20. 5. 2020.

Brkić, Vanja (2018): Na Habjanovem bajerju 58 stanovanj. Dnevnik. Accessible at https://www.dnevnik.si/1042841552/lokalno/ljubljana/na-habjanovem-bajerju58-stanovanj, 13. 5. 2020.

Facebook page of Civil initiaitve Rožna dolina. Accessible at https://www.facebook. com/CIRoznaDolina/, 12. 5. 2020.

Flyer 1 (2020): Vabilo na zbor meščank in meščanov Rožne doline. Accessible at https://www.facebook.com/CIRoznaDolina/photos/rpp.1206541339509283/1 593027917527288/?type=3\&theater, 12. 5. 2020.

Kos, David (2008): Podžupam MOL prof. Janez Koželj: Pripravljen sem prevzeti odgovornost za gradnjo v višino. Siol. Accessible at https://siol.net/novice/ slovenija/podzupan-mol-prof-janez-kozelj-pripravljen-sem-prevzeti-odgovornost-za-gradnjo-v-visino-339959, 30. 4. 2020.

Krivec, Tamara (2019): Sodnica razsodila, da Janković od Gratela ni zahteval podkupnine. Dnevnik. Accessible at https://www.dnevnik.si/1042877188, 20. 5. 2020.

Ljubljana (2007): Glasilo Mestne občine Ljubljana, številka 8,9: Vizija Ljubljana 2025 (XII). Ljubljana: Mestna občina Ljubljana.

Mekina, Borut (2018): Zoran Janković, župan Ljubljane. Mladina. Accessible at https://www.mladina.si/188149/zoran-jankovic-zupan-ljubljane/, 30. 4. 2020. 
Mestna občina Ljubljana (2010a): Odlok o občinskem prostorskem načrtu Mestne občine Ljubljana - strateški del. Accessible at https://www.ljubljana.si/assets/ OPN-MOL/2010-78-4263-NPB9.pdf, 21. 4. 2020.

Mestna občina Ljubljana (2010b): Odlok o občinskem prostorskem načrtu Mestne občine Ljubljana - izvedbeni del. Accessible at https://www.ljubljana.si/assets/ OPN-MOL/2010-78-4264-NPB20.pdf, 21. 4. 2020.

Mestna občina Ljubljana (2011): Odlok o občinskem prostorskem načrtu 209 Rožna dolina - center in za del enote urejanja prostora RD-254. Accessible at https://www.uradni-list.si/glasilo-uradni-list-rs/vsebina/2011-01-1992/odlok-oobcinskem-podrobnem-prostorskem-nacrtu-209-rozna-dolina--center-in-za-delenote-urejanja-prostora-rd-254, 21. 4. 2020.

Pahor, Peter (2017a): Občina bo omejila velikost vilablokov v Rožni dolini. Dnevnik. Accessible at https://www.dnevnik.si/1042789147/Ljubljana/obcina-bo-omejila-velikost-vilablokov-v-rozni-dolini, 3. 5. 2020.

Pahor, Peter (2017b): Zaradi garažne kleti bodo prej ali slej razpokale hiše. Dnevnik. Accessible at https://www.dnevnik.si/1042791963/lokalno/ljubljana/zaradigaraznih-kleti-bodo-prej-ali-slej-razpokale-hise, 4. 5. 2020.

Pahor, Peter (2019a): Rožnodolci zaustavili gradnjo luksuznih stanovanj. Dnevnik. Accessible at https://www.dnevnik.si/1042880399/lokalno/ljubljana/ roznodolci-zaustavili-gradnjo-luksuznih-stanovanj, 4. 5. 2020.

Pahor, Peter (2019b): Gradbena dovoljenja v Rožno dolini padajo kot za stavo. Dnevnik. Accessible at https://www.dnevnik.si/1042887706/lokalno/ljubljana/ gradbena-dovoljenja-v-rozni-dolini-padajo-kot-za-stavo, 3. 5. 2020.

Pahor, Peter (2020): V Rožni dolini še vedno gradijo vila bloke. Dnevnik. Accessible at https://www.dnevnik.si/1042925116/lokalno/ljubljana/v-rozni-dolini-sevedno-gradijo-vila-bloke, 4. 5. 2020.

Pahor, Peter in Tanja Lesničar-Pučko (2018): Janez Koželj: Smo na točki, ko bi se morali začeti ukvarjati z omejevanjem množičnega turizma. Dnevnik. Accessible at https://www.dnevnik.si/1042839748, 3. 5. 2020.

Petkovšek, Janez (2017a): Hočejo Rožno, ne betonske doline. Delo. Accessible at https://www.delo.si/novice/ljubljana/hocemo-rozno-ne-betonske-doline.html, 3. 5. 2020.

Petkovšek, Janez (2017b): Stop gradnji vilabokov v Rožni dolini! Delo. Accessible at https://www.delo.si/novice/ljubljana/stop-gradnji-vilablokov-v-rozni-dolini. html, 3. 5. 2020.

Petkovšek, Janez (2018): Hočejo novo kanalizacijo, ne novogradenj. Delo. Accessible at https://www.delo.si/lokalno/ljubljana-in-okolica/hocejo-novokanalizacijo-ne-novogradenj-54284.html, 2. 5. 2020.

Slovenia times (2017, Spring edition). Ljubljana: Domus. Accessible at https://issuu. com/thesloveniatimes/docs/tst_01_2017_lowres, 30.4. 2020.

Zabukovec, Mojca (2018): »Da preprečimo degradacijo Rožne doline, je naša ustavna pravica«. Delo. Accessible at https://www.delo.si/lokalno/ljubljana-in-okolica/da-preprecimo-degradacijo-rozne-doline-je-nasa-ustavna-pravica- 100639. html, 3. 5. 2020. 